This Journal is available in Telkom University online Journals

Jurnal Manajemen Indonesia

\title{
Impact of Activity Ratio, Profitability, Liquidity, and Asset Structure on Capital Structure in Food and Beverages Companies Listed On Indonesia Stock Exchange Period 2015-2019
}

\author{
Erni Martini ${ }^{1}$, Muhammad Adyb Ramli ${ }^{2}$, Tieka Trikartika Gustyana ${ }^{3}$, Nugraha ${ }^{4}$ \\ ${ }^{1,4}$ School of Postgraduate Program, Universitas Pendidikan Indonesia, Bandung, Indonesia \\ ${ }^{2,3}$ Faculty of Economic and Business, Telkom University, Bandung, Indonesia
}

\begin{abstract}
This study has an objective to examine the effect form activity ratio (TATO), liquidity (CR), profitability (ROA), and asset structure on capital structure (DER). Data processing uses financial reports from seventeen (17) $F \& B$ companies that listed on the Bursa Efek Indonesia (BEI) from period 2015 to 2019. A total of 425 data were used as samples using purposive sampling technique. Data panel regression used to analyze data and testing hypotheses. Results showed the simultaneous influence between the activity, liquidity, profitability, and asset structure to capital structure. Partially, activity ratio and asset structure variable do not affect capital structure. This study also proved that profitability affects capital structure in positive and significant relationship, while liquidity has a negative and significant effect to capital structure. Further findings are discussed in this study.
\end{abstract}

Keywords - Activity Ratio, Asset Structure, Capital Structure, Liquidity, Profitability

\begin{abstract}
Abstrak
Penelitian ini bertujuan untuk menganalisis pengaruh dari aktivitas (TATO), profitabilitas (ROA), likuiditas (CR), dan struktur aset terhadap struktur modal (DER) perusahaan. Data yang digunakan pada penelitian ini adalah data sekunder berupa laporan keuangan dari perusahaan-perusahaan yang bergerak di sub sektor makanan dan minuman yang terdaftar di Bursa Efek Indonesia (BEI) periode 2015 -2019. Sebanyak 17 perusahaan dengan 425 data digunakan sebagai sampel dan data penelitian menggunakan teknik purposive sampling. Data dianalisis menggunakan regresi data panel. Hasil penelitian menunjukkan pengaruh simultan antara aktivitas, profitabilitas, likuiditas, dan struktur aset terhadap struktur modal. Secara parsial, aktivitas dan struktur aset tidak berpengaruh terhadap struktur modal. Profitabilitas berpengaruh positif dan signifikan, sedangkan likuiditas berpengaruh negatif dan signifikan pada struktur modal. Pembahasan lebih lanjut disajikan pada pembahasan penelitian.
\end{abstract}

Kata kunci — Rasio Aktivitas, Struktur Aset, Struktur Modal, Likuiditas, Profitabilitas

\section{INTRODUCTION}

Determination in decisions related to capital structure is one of the important decisions in business ( Vu et al., 2020). Determining the company's capital structure will influence the company's funding sources in the future, cost of capital, risk character, liquidity position, investor return and firm valuation (Bajaj et al., 2020). Furthermore, the description of the company's capital structure will be used as portrayed of the company's permanent financial financing, either from internal capital or from long-term debt.

Companies could increase capital through additional capital loans if the debt obtained by the company is below the predetermined target (Margaretha, 2014). Additional loan capital can come from internal and external funds and be used to strengthen the company's capital structure. Financial managers need to know the factors that affect the strengthening of the capital structure, that is including activity, profitability, liquidity, asset structure, asset 
growth, firm size, growth opportunity, institutional ownership, and asset structure (Salim \& Susilowati, 2019; Arlita \& Surjandari, 2019; Ahmad et al., 2017).

Strengthening the capital structure will help companies to face business competition. Competition in the F\&B subsector increases year after year. The tendency of the community to consume ready-to-eat food growing many new competitors in this industry (Mardianti, 2019). Some attempt that these companies can do to win the competition are by creating product innovation, expanding the market, intensify quality human resources and other activities to increase company value (Dewiningrat \& Mustanda, 2018).

Knowledge about factors that able to influence capital structure are very important in considering the composition of the company's capital structure. Previous study showed different factor that has positively and negatively affect capital structure. Watung et al. (2016) stated that liquidity, activity, profitability, and asset structure affect capital structure. Primantara and Dewi (2016) also found that there are several factors that influence capital structure which are liquidity, profitability, business risk, company size, and taxes. According to Dewiningrat and Mustanda (2018) liquidity, profitability, sales growth, and asset structure become the factor that affect capital structure. Eviani (2015) added factors that influence capital structure, namely asset structure, sales growth, dividend payout ratio, liquidity, and profitability. Finally, Ismaida and Saputra (2016) found several factors that affect the capital structure, which are sales growth, profitability, sizes and company activity. These finding show different variables that affect capital structure. Thus, the effect from different variable to capital structure also show inconsistency results in in terms of effect relations. This inconsistency results became an important research gap to be discuss further. Graphic 1 showed the percentage of ratio on activity, profitability, liquidity, and asset structure in F\&B companies in Indonesia from 2015 until 2019.

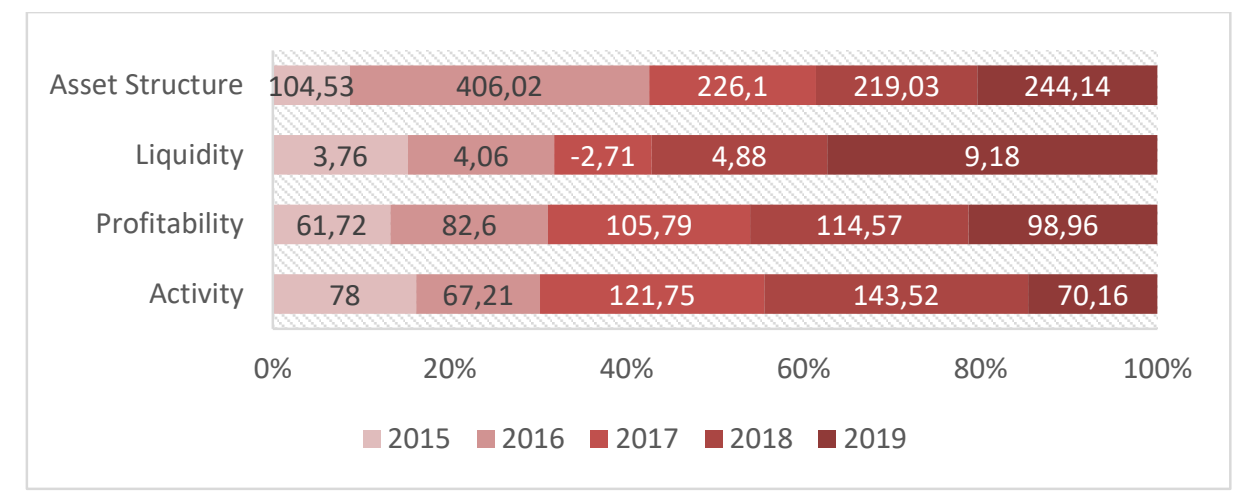

Figure 1 Average on activity, profitability, liquidity, and asset structure ratio in F\&B companies in Indonesia year 2015-2019 (Source: Company Financial Statement 2015 - 2019)

Figure 1 showed the fluctuation average in activity, profitability, liquidity, and asset structure ratio in F\&B companies in Indonesia during 2015 - 2019. The most extraordinary condition occurred in 2017 where the average liquidity ratio was at $-2.71 \%$, which indicates a liquidity problem in F\&B companies. Also, in 2018 and 2019 , there was a decrease in profitability and activity, but there was a very significant increase in the asset structure and liquidity. This indicates an uncertain financial condition which can affect capital structure for each company. Since activity ratios, profitability, liquidity, and asset structure are factors that most used to enhance capital structure in the previous study but also have inconsistent result for the effect relation towards capital structure, this research will focus to investigate the relation between those variables.

Based on the problem phenomenon that has been described, problem statement that posed in this study was asking whether there is an effect of activity ratios, profitability, liquidity, and asset structure on capital structure in food and beverage subsector companies listed on the Indonesia Stock Exchange for the period 2015-2019. The finding from this research would provide a latest and new overview that can be different from the result in previous studies. 


\section{LITERATURE REVIEW}

\section{A. Capital Structure}

The capital structure is a picture of permanent financial financing of a company which consists of own capital and long-term debt (Van-Horne \& Wachowicz, 2008). According to Hirdinis (2019), if the value of capital structure increases, the value of company will also increase. The capital structure calculation method used in this study is the Debt-to-Equity Ratio (DER).

Brigham \& Houstan (2001) argues that capital structure is influenced by asset structure, financial flexibility, tax, growth, firm size, operating leverage, sales stability, profitability, controlling, and management attitude. Other research results were put forward by Salim \& Susilowati in 2019 which stated that profitability, liquidity, assets growth and firm size simultaneously affect the capital structure. Ahmad et al (2017) proves that profitability, asset structure, firm size and liquidity have a simultaneous effect capital structure.

Vu et al., 2020 examined the influence of the board size, the board independence, and especially different ownership structures, which include the managerial ownership, the state ownership, the concentrated ownership, and the foreign ownership of the capital structure in Vietnam. Vu et al research proved that only the board size, state ownership and concentrated ownership have a positive impact, while foreign ownership has a negative effect on capital structure. Also, in $\mathrm{Vu}$ et al finding, there are clear evidence that board independence, managerial ownership and corporate capital structure have no impact on capital structure in Vietnam.

Furthermore, the results form Salim \& Susilowati (2019) suggest that each company needs to find specific factors that may be concerned to have affect in company's capital structure, this is because each company has different capital requirements. Based on the finding regarding capital structure, the first hypothesis proposed are:

H1: Activity, profitability, liquidity, and asset structure simultaneously influence capital structure.

\section{B. Activity Ratio (Total Asset Turnover)}

Total Asset Turnover (TATO) is an indicator of company efficiency that reflects how much capital is invested from the total capital that is rotated to achieve company turnover (Serghiescu et al., 2014). TATO usually used to measure the effectiveness of the companies in managing all its assets and generating maximum revenue from sales (Wijaya, 2017). The method of calculating the activity ratio used in this study is the Total Assets Turnover (TATO).

Previous research that examining the relationship between asset turnover and capital structure give an evidence that total asset turnover has no effect on capital structure (Arilyn, 2020; Watung et al., 2016; Noviandini \& Welas, 2017). However, other studies have found that TATO has negative and insignificant negative impact on capital structure (Wardhana \& Mawardi, 2016; Situmeang et al., 2019). The results of research related to asset turnover still vary and can be further elaborated to strengthen the different results from previous studies. Based on these findings, the second hypothesis proposed are:

H2: Total asset turnover effect capital structure in significant relationship.

\section{Profitability (Return on Asset)}

Profitability ratio usually used to assess the company's ability in achieve advantages or profit in a certain period (Kasmir, 2014). The method of calculating the profitability ratio that used in this study is the Return on Assets (ROA). Previous research has given a result to prove that profitability has a negative impact on capital structure (Arilyn, 2020; Ahmad et al., 2017; Salim \& Susilowati, 2019). However, Arlita's research (2019) found that profitability had no partial effect on structure capital. Based on these findings, the third hypothesis proposed are:

H3: Profitability effect capital structure in significant relationship.

\section{Liquidity (Current Ratio)}

Liquidity ratio is used to evaluate a company's ability in settle a short-term debt (Wijaya, 2017). This study used Current Ratio (CR) as the method to calculating the liquidity. Research that examines the impact of liquidity on capital structure shows a positive effect to capital structure (Arlita, 2019). On the other hand, other studies have shown that liquidity has a significant effect to capital structure (Arilyn, 2020; Salim \& Susilowati, 2019; Ahmad et al., 2017). Based on these findings, the fourth hypothesis proposed are: 
H4: Liquidity effect capital structure in significant relationship.

\section{E. Asset Structure (Fixed Asset Ratio)}

Asset structure is the company's wealth or economic resources which are expected to provide benefits in the future (Hutasuhut et al., 2014). There have been many studies examining the influence relationship between asset structure and capital structure. Previous research results prove that asset structure affects capital structure (Arlita, 2019; Ahmad et al., 2017). The method of calculating the asset structure used in this study is Fixed Asset. Based on result from previous study, the fifth hypothesis proposed are:

H5: Asset structure effect capital structure in significant relationship.

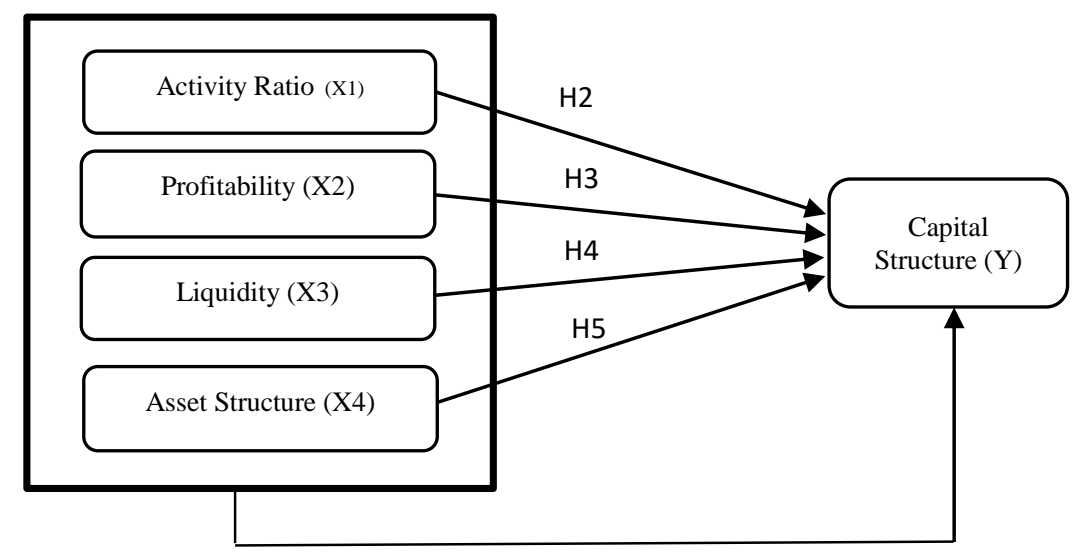

H1

Figure 2 Research Framework

\section{RESEARCH METHOD}

This research is a quantitative study to verify the findings from previously researches. $\mathrm{F} \& \mathrm{~B}$ companies that listed on the Bursa Efek Indonesia (BEI) in 2015-2019 were chosen to be population in this research. The total population that has been used was 17 companies and total of 425 data are collected using purposive sampling technique. To test the hypothesis, panel data regression was used. The dependent variable of this study is the capital structure, while the independent variable consists of 4 variables, which are total asset turnover, profitability, liquidity, and asset structure. The panel data regression analysis equation is written as follows:

$$
\mathrm{Y}=\alpha+\beta_{1} \mathrm{X}_{1 \mathrm{it}}+\beta_{2} \mathrm{X}_{2 \mathrm{it}}+\beta_{3} \mathrm{X}_{3 \mathrm{it}}+\beta_{4} \mathrm{X}_{4 \mathrm{it}}+\mathrm{e}
$$

$\mathrm{Y}$
$\alpha$
$\beta_{1}, \beta_{2}, \beta_{3}, \beta_{4}$
$\mathrm{X}_{1}$
$\mathrm{X}_{2}$
$\mathrm{X}_{3}$
$\mathrm{X}_{4}$
$\mathrm{e}$

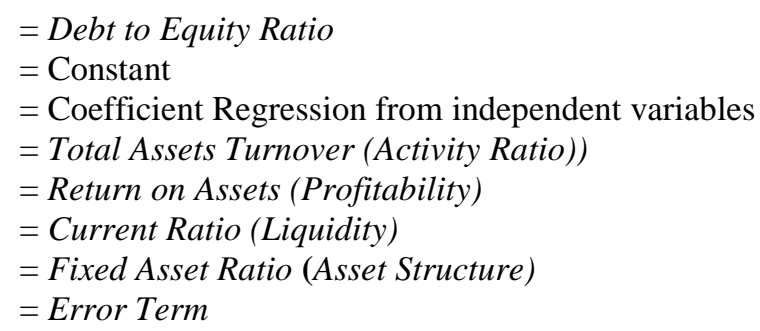

\section{RESUlT AND DISCUSSION}

A. Result

Based on the list of companies that listed on the Bursa Efek Indonesia (BEI) for the period 2015 - 2019, 17 companies engaged in the F\&B sub-sector were obtained. The list of company names is shown in table 1. 
Table 1 List of Company

\begin{tabular}{ccl}
\hline No & Company Code & \\
\hline 1 & ADES & PT Akasha Wira International Tbk. \\
2 & AISA & PT Tiga Pilar Sejahtera Food Tbk. \\
3 & ALTO & PT Tri Banyan Tirta Tbk. \\
4 & BTEK & PT Bumi Teknokultura Unggul Tbk. \\
5 & BUDI & PT Budi Starch dan Sweetner Tbk. \\
6 & CEKA & PT Wilmar Cahaya Indonesia Tbk. \\
7 & DLTA & PT Delta Djakarta Tbk. \\
8 & ICBP & PT Indofood CBP Sukses Makmur Tbk. \\
9 & IIKP & PT Inti Agri Resources Tbk. \\
10 & INDF & PT Indofood Sukses Makmur Tbk \\
11 & MLBI & PT Multi Bintang Indonesia Tbk. \\
12 & MYOR & PT Mayora Indah Tbk. \\
13 & PSDN & PT Prashida Aneka Niaga Tbk \\
14 & ROTI & PT Nippon Indosari Corporindo Tbk. \\
15 & SKLT & PT Sekar Laut Tbk. \\
16 & STTP & PT Siantar Top Tbk. \\
17 & ULTJ & PT Ultrajaya Milk Industry and Trading Companies \\
\hline
\end{tabular}

Furthermore, from the financial statements of these 17 companies, 425 data were obtained which were processed using e-views software to answer the research hypothesis. The results of this research hypothesis test are shown in table 2.

Table 2 Summary of Common Effect Model

\begin{tabular}{crrrr}
\hline Variable & Coefficient & Std. Error & \multicolumn{1}{c}{ t-Statistic } & \multicolumn{1}{c}{ Prob. } \\
\hline C & 1.286064 & 0.255768 & 5.028248 & 0.0000 \\
X1 & -0.066761 & 0.159234 & -0.419263 & 0.6761 \\
X2 & 0.727886 & 0.319722 & 2.276619 & 0.0255 \\
X3 & -0.191230 & 0.058867 & -3.248503 & 0.0017 \\
X4 & 0.152857 & 0.163851 & 0.932903 & 0.3537 \\
\hline ROOT MSE & 0.889914 & & R-squared & 0.171167 \\
Mean dependent. Var. & 0.923756 & & Adjusted R-squared & 0.129725 \\
S.D. depent var & 0.983296 & S.E. of Regression & 0.917302 \\
Akaike info criterion & 2.722263 & & Sum squared resid & 67.31550 \\
Schwarz criterion & 2.865959 & & Log Likehood & -110.6962 \\
Hannan-Quinn criter. & 2.780058 & & F-Statistic & 4.130309 \\
Durbin-Watson stat. & 0.509591 & & Prob (F-Statistic) & 0.004299 \\
\hline
\end{tabular}

Based on table 2, the coefficient value of the common model effect can be shown so that the panel data regression equation model for this research can be written as follows:

Capital Struc. $(Y)=1.286064-0.066761(X 1)+0.727886(X 2)-0.191230(X 3)+0.152857(X 4)+e$

The Adjusted R-Square value in this study obtained a value of 0.129725 . From these results, it can be interpreted that the capital structure $12,97 \%$ can be explained by activity, profitability, liquidity and asset structure, and remaining of $87.03 \%$ is explained by the other factors thereout this research.

To answer the research hypothesis, the probability value is used as a determining parameter for acceptance or rejection of the hypothesis. Based on the probability values in table 1, it can be explained:

1. Value of Prob. (F statistic) is 0.004299 which is smaller than 0.05, then H0 is rejected and H1 is accepted. It can be interpreted that the activity, profitability, liquidity, and asset structure had simultaneously and significantly effects capital structure in F\&B companies. 
2. The probability value of activity ratio (X1) is 0.6761 , this value is greater than the alpha value 0.05 , so it can be interpreted that $\mathbf{H} \mathbf{2}$ is rejected. Partially, activity ratio has no significant effect to capital structure.

3. The probability value of profitability (X2) is 0.0255 , this value is smaller than the alpha value 0.05 , so it can be interpreted that $\mathbf{H 3}$ is accepted. Partially, profitability effect capital structure in significant and positive relationship.

4. The probability value of liquidity (X3) is 0.0017 , this value is smaller than the alpha value 0.05 , so it can be interpreted that $\mathbf{H 4}$ is accepted. Partially, liquidity affect capital structure in negative and significant relationship.

5. The probability value of asset structure $(\mathrm{X} 4)$ is 0.3537 , this value is greater than the alpha value 0.05 , so it can be interpreted that $\mathbf{H 5}$ is rejected. Partially, asset structure do not affect capital structure.

\section{B. Discussion}

Based on this finding, this study shows the result between activity ratios (X1), profitability (X2), liquidity (X3), and asset structure (X4) that effect capital structure (Y) in significant and positive relationship. The results from F-test prove that the capital structure in the F\&B companies' sub-sector is influenced by liquidity, activity, profitability, and asset structure. It means that decreasing or increasing in the capital structure value of the F\&B companies depends on by their asset turnover, return on assets, current ratio, and fixed assets as part of financial activities results. This result confirmed previous results conducted by Watung et al (2016) which states that liquidity, activity, profitability, and asset structure simultaneously affect capital structure. Therefore, companies need to emphasize these factors in order not to decrease their capital structure. This finding also indicates companies to give more attention to liquidity, activity, profitability, and asset structure in using their own capital and long-term debt as sources of internal or external funds that can be useful to strengthen the capital structure and company's operational activities.

Result for activity ratios on capital structure in this study shows that there is no influence between activity ratios on capital structure. This finding is in accordance with the results from previous research from Arilyn (2020), Watung et al (2016), and Noviandini \& Welas (2017) which also have no effect on the variable activity ratio to capital structure. However, result from this study are not consistent with the effect of research by Wardhana \& Mawardi (2016) and Situmeang et al (2019) which show a negative influence between asset turnover and capital structure. These varying results can be caused by differ characteristic of industry that make the necessity for a partial capital structure different with one another.

The result on profitability on capital structure in this study shows that there is a significant and positive relationship to capital structure. This can be interpreted that, high profitability value will also increase retained earnings which can be used as a source of internal funding to increase corporate profits. A high level of profitability can improve the capital structure, which causes creditors to be interested in considering giving debt to the company. This study has the same result with the research that have been conducted by Watung et al. (2016), Dewi and Sudiartha (2017), Thaib and Dewantoro (2017), and Ismaida and Saputra (2016) which state that profitability has a positive and significant effect on capital structure. But this finding also has inconsistent result with Arylin (2020), Salim (2019), Ahmad et al. (2017) which stated that profitability has a negative and significant effect on capital structure.

The result on liquidity to the capital structure is partially proven to have a negative and significant effect. This result has the same output form Watung et al. (2016), Ahmad et al. (2017), Dewiningrat and Mustanda (2018), Arilyn (2020), Eviani (2015), Ghasemi and Razak (2014), Thomas et al. (2014), and Salim \& Susilowati (2019) which state that liquidity and capital structure has a negative and significant effect. With the output in this study, it can be analyzed that the current activity of F\&B companies is higher than the debt that must be fulfilled. The high amount of current assets makes the company able to pay off its short-term debt. From this study, there was clear evidence that indicate the level of liquidity of F\&B companies in 2015-2019 reduces the amount of capital structure that owned by the company.

The effect of asset structure on capital structure shows no effect. This result is different from previous studies from Eviani (2015), Priambodo et al. (2014), Alipour et al. (2015), Kanita (2014), Arlita (2019), and Ahmad et al (2017) who get the results that asset structure affects capital structure. This result is a valuable finding from this study by proving that the asset structure does not affect the capital structure in F\&B companies. 


\section{CONCLUSION AND RECOMMENDATION}

The results of this study found that the activity ratio, profitability, liquidity, and asset structure simultaneously affected capital structure significantly. The activity ratio and asset structure partially do not affect capital structure. Then, the ratio of profitability and liquidity partially has a positive yet significant effect. These findings are obtained by using the constraints from 5 years period of data in F\&B companies. Future studies can add the period to be observed with the result that can be compare in similar conditions in different countries. Other studies can also add variables that are not studied in this research such as asset growth, firm size, growth opportunity, institutional ownership, and asset structure as independent variables to obtain more significant results for the dependent variable of capital structure.

\section{REFERENCES}

Ahmad, G. N., Lestari, R., \& Dalimunthe, S. (2017) 'Analysis Of Effect Of Profitability, Assets Structure, Size Of Companies, And Liquidity To Capital Structures In Mining Companies Listed In Indonesia Stock Exchange Period 2012-2015', JRMSI-Jurnal Riset Manajemen Sains Indonesia, 8(2), 339-354.

Alipour, M., Mohammadi, M. F. S., Derakhshan, H. (2015) 'Determinants of capital structure: an empirical study of firms in Iran', International Journal of Law and Management.

Arilyn, E. J. (2020) 'The Effects of Profitability, Liquidity, Tangibility, Firm Size, and Asset Turnover on Capital Structure in Chemical Industry Listed on Indonesia Stock Exchange From 2014 to 2018', The 8th International Conference of Entrepreneurship and Business Management Untar (ICEBM 2019) (pp. 399-404). Atlantis Press.

Arlita, D. P., \& Surjandari, D. A. (2019) 'The Effect of Profitability, Liquidity, Asset Structure, Growth Opportunity, Institutional Ownership on Capital Structure (Case Study at Property and Real Estate Companies in Indonesia Stock Exchange Period 2013-2017)’, Sch Bull, 5(8): 461-470

Bajaj, Y., Kashiramka, S., \& Singh, S. (2020) 'Application of capital structure theories: a systematic review', Journal of Advances in Management Research.

Brigham, F., Eugene, dan Joel, F Houston. (2001) Financial Management II, Jakarta: Salemba Empat

Dewi, D. Y., dan Sudiartha, G. M. (2017) 'Pengaruh Profitabilitas, Ukuran Perusahaan, dan Pertumbuhan Aktiva Terhadap Struktur Modal dan Nilai Perusahaan', E-Jurnal Manajemen Unud, 2222-2252

Dewiningrat, A. I., dan Mustanda, I. K. (2018)' Pengaruh Likuiditas, Profitabilitas, Pertumbuhan Penjualan, dan Struktur Aktiva Terhadap Struktur Modal', E-Jurnal Manajemen Unud, 3471-3501.

Eviani, A. D. (2015) 'Pengaruh Struktur Aktiva, Pertumbuhan Penjualan, Dividen Payout Ratio, Likuiditas, dan Profitabilitas terhadap Struktur Modal', Jurnal Akuntansi dan Sistem Teknologi Informasi Vol 11, 194-202.

Ghasemi, M., dan Razak, N. H. A. (2016) 'The Impact of Liquidity on the Capital Structure: Evidence from Malaysia', International Journal of Economics and Finance, Vol. 8, No. 10.

Hirdinis, M. (2019) 'Capital Structure and Firm Size on Firm Value Moderated by Profitability', International Journal of Economics and Business Administration Volume VII, Issue 1, 201

Hutasuhut, M. H., Ratnawati, V., \& Alamsyah, M. (2014) 'Analisis Faktor-faktor yang Mempengaruhi Struktur Modal pada perusahaan yang tergabung dalam Jakarta Islamic Index di Bursa Efek Indonesia tahun 2009 2012', JOM Fekon Vol 1 No 2.

Ismaida, P., dan Saputra, M. (2016) 'Pengaruh Pertumbuhan Penjualan, Profitabilitas, Ukuran, dan Aktivitas Perusahaan Terhadap Struktur Modal Pada Perusahaan Property dan Real Estate Yang Terdaftar Di BEI Periode 2012-2014', Jurnal Ilmiah Mahasiswa Ekonomi Akuntansi, 221-229.

Kanita. (2014) 'Pengaruh Struktur Aktiva dan Profitabilitas terhadap Struktur Modal Perusahaan Makanan dan Minuman', Trikonomika, Vol. 13, No. 2.

Kasmir, D. (2014) Financial Statements Analysis, Rajagrafindo Persada.

Mardianti, L. (2019) 'Pengaruh Leverage, Struktur Modal, dan Pertumbuhan Perusahaan terhadap Nilai Perusahaan pada F\&B', Jurnal Ilmu dan Riset Manajemen (JIRM), 8(4).

Margaretha, F. (2014) Dasar-Dasar Manajemen Keuangan, Jakarta: Penerbit Dian Rakyat. 
Noviandini, N., \& Welas, W. (2017) 'Pengaruh Current Ratio, Return on Asset Dan Total Asset Turnover terhadap Struktur Modal pada Perusahaan Publik Sub Sektor Makanan dan Minuman Periode 2011-2015', Jurnal Akuntansi dan Keuangan, 6(1), 1-19.

Priambodo, T. J., Topowijono, dan Azizah, D. F. (2014) 'Pengaruh Struktur Aktiva, Tingkat Pertumbuhan Penjualan dan Profitabilitas terhadap Struktur Modal', Jurnal Administrasi Bisnis (JAB) Vol 9 No 1.

Primantara, A., dan Dewi, M. R. (2016) 'Pengaruh Likuiditas, Profitabilitas, Risiko Bisnis, Ukuran Perusahaan, dan Pajak Terhadap Struktur Modal', E-Jurnal Manajemen Unud, 2696-2726.

Salim, M. N., \& Susilowati, R. (2019) 'The Effect of Internal Factors on Capital Structure and Its Impact on Firm Value: Empirical Evidence from The Food and Beverages Industry Listed on Indonesia Stock Exchange 20132017', International Journal of Engineering Technologies and Management Research, 6(7), 173-191.

Serghiescu, L., \& Văidean, V. L. (2014) 'Determinant factors of the capital structure of a firm-an empirical analysis', Procedia Economics and Finance, 15, 1447-1457.

Situmeang, A. L., Siagian, S., Sigalingging, N., \& Samosir, Y. G. (2019) 'Pengaruh Rasio Profitabilitas (ROA), Rasio Likuditas (CR) dan Rasio Aktivitas (TATO) terhadap Struktur Modal (DER) pada Perusahaan Basic Industry and Chemicals di Bursa Efek Indonesia Periode 2014-2018', Jurnal Ilmiah Socio Secretum, 9(1), 113

Thaib, I., dan Dewantoro, A. (2017) 'Pengaruh Profitabilitas dan Likuiditas Terhadap Nilai Perusahaan dengan Struktur Modal sebagai Variabel Intervening', Jurnal Riset Perbankan Manajemen dan Akuntansi.

Thomas, Chenuous., dan Biwott. (2014) 'Do Profitability, Firm Size and Liquidity Affect Capital Structure? Evidence from Kenyan Listed Firms', European Journal of Business and Management, Vol. 6, No. 28.

Van Horne, James, John M. Wachowicz. (2008) Fundamentals of Financial Management 13th Edition, Prentice Hall. England

Vu, T. M. T., Tran, C. Q., Doan, D. T., \& Le, T. N. (2020) 'Determinants of capital structure: The Case in Vietnam', The Journal of Asian Finance, Economics, and Business, 7(9), 159-168.

Wardhana, I. B. J., \& Mawardi, W. (2016) 'Analisis Pengaruh Struktur Aktiva, Asset Turnover, Growth Terhadap Profitability Melalui Variabel Capital Structure Sebagai Variabel Intervening (Studi Kasus pada Perusahaan Consumer Goods BEI Periode Tahun 2012-2014)', Diponegoro Journal of Management, 5(2), 498-511.

Watung, A. S., Saerang, I., dan Tasik, H. (2016) 'Pengaruh Rasio Likuiditas, Aktivitas, Profitabilitas, dan Struktur Aktiva Terhadap Struktur Modal Industri Barang Konsumsi di Bursa Efek Indonesia', Jurnal EMBA, 726-737.

Wijaya, D. (2017) Manajemen Keuangan Berbasis IFRS, Yogyakarta: Penerbit Gava Media 